fact is that more and more colleges and universities are identifying their library staffs with the academic group. It is Dr. Downs's firm conviction that over the years the full identification of librarians with the faculty, with all the rights and privileges which this status implies, will create the best kind of library service to students and faculty. And, of course, he is fundamentally right. In time the second class status and/or "separate but equal" status will eventually become anomalous. This is not to suggest that every head librarian or professional library staff that has not yet reached faculty status should rush headlong into the battle, armed with copies of this report, to demand full faculty privileges. Neither should the head librarian or library staff that has not yet achieved all that Dr. Downs and others have in terms of status for professional librarians feel miserable, downcast, and frustrated. Too much preoccupation with staff status leads to fancied grievances, to dulling the imagination, and to the forming of a hard defensive crust on the mind which results in inflexibility. Dr. Downs and his contributors say clearly what must be done to achieve a satisfactory staff status. If conditions at Illinois and elsewhere seem somewhat remote from one's present situation, be of good cheer because if one has imagination, if he has a clear-cut conception of the library's role in the college or university, if he takes every reasonable opportunity to make known the nature and importance of this role, and if in public performance and personal conviction he measures library success in terms of quality rather than quantity, then in good time all librarians-from the head librarian to the beginning professional librarian-will be accepted fully as members of the instructional or academic staff of the college or university.

As every good compiler should, Dr. Downs introduces the authors and pages contained in this monograph by precise reference to the source of the maiden publication, and also summarizes the major points or purpose of each contribution. Apparently all but two of the articles have been previously published. They include Paul H. Buck's “A New Personnel Program for Harvard Librarians," Patricia Knapp's "The College Librarian: Sociology of a Professional Spe- cialization," William H. Carlson's "The Trend Toward Academic Recognition of College Librarians," Robert H. Muller's "Faculty Rank for Library Staff Members in Medium-Sized Universities and Colleges," Felix Reichmann's "Hercules and Antaeus," Lawrence Thompson's "Preparation and Status of Personnel," Sidney H. Ditzion's "College Librarians and the Higher Learning," the Lundy and Gelfand studies previously mentioned in this review, and three contributions by the editor himself. Lewis C. Branscomb's "The Quest for Faculty Rank" (that title gives me a haunting sense of exile from a passionate paradise) and Robert M. Pierson and Howard Rovelstadt's "The Case of Faculty Status for Librarians" appear here for the first time in public print.

The whole book-though perhaps, it is less a book than a series of papers-makes an eloquent appeal on behalf of the importance of librarianship and its being highly regarded and intelligently rewarded by the institutions whom the librarians serve. One might hope that such a book was quite unnecessary, but even in these days no one can say that it is not needed, in view of the amount of shallow depreciation that is current in some places by administrators and faculty members who ought to know better -and frequently do, because in public address they continue to refer to the library as "the heart of the institution." This leads one to the optimistic conclusion that colleges and universities may get along without full recognition for librarians as faculty members but they cannot get along without libraries.-Guy R. Lyle, Emory University Library.

\section{Industrial Information}

Information and Communication Practice in Industry. Edited by T. E. R. Singer. New York: Reinhold Publishing Corp., 304p., $\$ 8.75$.

Present practices and services in industrial libraries and information departments are discussed in this book. The distinction between an industrial library and an information department is not a sharp one. The industrial library which collects, abstracts, or- 
ganizes, and translates published literature is sometimes called an information department for reasons of prestige and/or to get the librarian into a higher pay classification. More often than not, however, the information department handles internal as well as external (published) literature and has technical writing and editing functions. The broader definition of an information department is accepted in this book. The introductory survey-type chapter lists and briefly describes operations in a special library and gives some budget data. The other chapters range from the "how-to-do" type (the four chapters on patent searching, technical writing, illustrating, and editing) to theoretical discussions (the three chapters on linguistics, language and terminology, indexing and classification). There are also chapters on operations research as applied to information work, the organization of internal research records and classified patent collections, mechanical aids for proper presentation, punched card techniques, translating and abstracting, and the training of literature scientists.

Since the entire gamut of information activity is covered in a relatively thin though expensive book, it is not surprising that most of the subjects included are covered in greater detail someplace else. This is particularly true with technical writing, technical editing, and punched card techniques. The chapter on the organization of research records is a notable exception in that it is more extensive than anything which has been seen by this reviewer thus far. No correspondingly comprehensive articles on abstracting and translating are available. The two chapters in this book are a good start; it is hoped that a more definitive work will soon be forthcoming.

After reading many books and articles in this field many of us are left with the impression that all this is very interesting but it does not really apply to our specific problems. The reader of this book is likely to come to the same conclusion, but he will also be exposed to a number of stimulating ideas and will have excellent bibliographies available on most of the subjects covered. It is for these two reasons that the book is recommended to special librarians in industry as well as in public, university, and gov- ernment libraries.-Gerald Jahoda, Technical Information Division, Esso Research and Engineering Co.

\section{Mass Communications Research}

Introduction to Mass Communications Research. Edited by Ralph $O$. Nafziger and David M. White. Baton Rouge: Louisiana State University Press, 1958. 244p. \$5.00.

Even after reading the book, the temptation is great to quote extensively from the preface, in which the editors so well describe their intent, for the reader's judgment of their success in fulfilling that intent will vary inversely with his own prior knowledge of and experience with scientific research methodology in the social sciences. Eschewing quotation, it is at least necessary to note that this volume is a lineal successor to the earlier (1949) An Introduction to Journalism Research, also sponsored by the Council on Communications Research of the Association for Education in Journalism. The title was broadened from "journalism" to "mass communications," even as the scope was narrowed from all of research methodology to "concentrate on research methods in mass communication from a behavioral point of view."

The intent is to acquaint new graduate students in the field of journalism with the research methodology now available for approaching the many and expanding problems in the field; to an extent the book is also an outline of procedure from the inception of a problem, through its planning, to the statistical interpretation of the data. As such it will also be useful to students in librarianship bent on following and broadening the trail blazed by Waples and Berelson.

The volume contains seven essays by as many authors on such topics as planning; experimental, field, and statistical methods; and "The Challenge to Communication Research." Since all of the authors are working over pretty much the same material from individual points of view, there is a goodly amount of repetition, which, for 